\section{Dichroism of Crystals}

ON May 5 and 12, 1836, Henry Fox Talbot (1800-77), the pioneer of photography, read a paper to the Royal Society entitled "On the Optical Phenomena of Certain Crystals", in which he gave an account of the optical properties of certain minute crystals, obtained by the evaporation of a solution of borax in phosphoric acid, when they were examined by the polarising microscope.

In a postscript to the paper, the author gave an account of a new species of 'dichroism' in crystals, to the discovery of which he was led by applying to them his peculiar method of observation with polarised light. In these experiments the crystals themselves performed the office of the analysing plates, acting on light previously polarised and transmitted through a plate of mica. The experiments tended to confirm the views of Sir David Brewster and others as to the general cause of the dichroism of crystals.

\section{Royal Asiatic Society and India}

AT the thirteenth anniversary meeting of the Royal Asiatic Society held on May 7, 1836, the Right Hon. C. W. W. Wynn (1775-1850), who had been president of the Society since its formation in 1823 , in his address said that "He felt particular gratification in congratulating the meeting on the proposal which had been laid before the Society, for establishing a Committee of Agriculture and Trade in relation to the East. . . . The plan just alluded to would be the means of introducing into India the useful discoveries of Europe in arts and sciences, but in the encouragement lately given by government to a more extended and unrestrained intercourse with the East would be found the true efficient for these ends. ... As the proposal relative to Trade and Agriculture must, if carried into effect, produce increased means of acquiring information on the capacity of the different nations of the vast Empire of India, he hoped it would meet with encouragement, not only from the Society, but from those engaged in commercial intercourse with the East." (Athenoeum.)

\section{Societies and Academies \\ PARIS}

Academy of Sciences, March 23 (C.R., 202, 993-1124). ERnEst Esclangon: The application of the principle of relativity to the study of a dynamical problem. Marcer Delípine and Alain Horeav: The hydrogenation of carbonyl compounds by Raney nickel, coated with metals of the platinum family. The influence of alkalis. The presence of a trace of alkali is essential for the hydrogenation. Experiments were made with ruthenium, palladium, osmium, iridium and platinum as coating for the nickel. All these metals increase the velocity of addition of hydrogen, palladium being the least active, platinum, iridium and osmium the most active. LUDOVIC MrazeC was elected Correspondant for the Section of Mineralogy, in succession to the late H. F. Osborn. B. Hostinsky : Probabilities in chain. ANDRÉ WeIr : The overlapping of topological spaces : complete spaces, bicompact spaces. NIKOLA OBREchKoFF : Asymptotic formulæ for Jacobi polynomials, and on the development along the polynomials. KaRL MENGER : Calculation of the variations in general spaces. I. Petrowsky : Cauchy's problem for a system of partial differential equations in the real domain. PIERre Rachevsky : A scheme unifying the theory of abstract groups with Lie's theory of infinitesimal groups. F. H. VAN DEN DUNGEN Small movements of a system submitted to gyro. scopic forces. Edgar Pifrre Tawil: A piezo. electric chronograph. The instrument described is capable of measuring to $1 / 100,000$ of a second. E. DE LA VIlLEMarqú: : The calculation of linear transformations, met with in astronomy, by the combined use of the machine and the method of mobile bands. L. SAckmanN : The study of certain discontinuities in the experimental determination of the polars of [aeroplane] wings. PAUL ScHwarz: The Bénard-Kármán vortices behind an obstacle, in movement in a rectilinear canal. LOUIS BREGUET: The optimum tonnage of large aeroplanes for use in transport or bombardment. JEAN DELSARTE : A problem of diffraction. Walter M. Elsasser : The diffraction of slow neutrons by crystalline substances. Pierre Jolivet : A new electrostatic motor. Ret Planiol : The ionisation and luminescence of atomic jets in a high vacuum. Moshé Feldenkrais : Measurement of the voltage of a Van der Gras electrostatic generator with belts. G. KRAvTzorr: The anodic behaviour of organic salts of copper. L. NEEL : The influence of the thermal variation of the molecular field on the Curie constant. Thadk PeCZalski : Widening of the lines of the radiation from 'singing' arcs. Charles SanNIf́, LdoIEN Amx and Vladimir Porkmskr: The isolation of the triplet $4358 \mathrm{~A}$. of the mercury are for use in obtaining Raman spectra. The filter proposed is a solution of nitrobenzene (6 per cent) and rhodamine 5G extra $(0.01$ per cent) in ethyl alcohol. JEAN RoIG: The temperature of helium in the high-frequency discharge. Although the conditions of the tube varied between wide limits, the temperature always ro. mained in the neighbourhood of $200^{\circ} \mathrm{C}$. Paur Solwrllet and Serge NIKITINE: The polarisation of the radiation $2139 \mathrm{~A}$. emitted by the optical resonance of a jet of zinc atoms. RENÉ AUDUBREs and M. Prost : A radiation emitted during the hydration and dehydration of quinine sulphate. An ultra-violet radiation, between $2500 \mathrm{~A}$. and $2000 \mathrm{~A}$. was proved to accompany these changes in water content. MLLe. HoANG THI NGA: The influence of the nature and position of the groups on the photo. potential of the substituted aromatic amines. M. E. NaHMras : The artificial radioactivity of tin. A very slight artificial radioactivity has been produced in tin by irradiation with a radon-beryllium sourco. Mme. Emmanuel Zavizziano : Adsorption of protactinium by titanium, and the method of fractionation. Arex SanielevicI : Calorimetric measurements of the energy of disintegration in the actinium family. Marcel LeconN: The continuous $\beta$-spectrum of actinium B. RAYMOND LAUTIÉ : A general constant of Van der Waals. J. TImmermans, M. Hennaut. Roland and D. Rozental : The variation of the volume of heavy water on freezing. The difference of the specific volumes of heavy water in the liquid and solid states is 0.0811 : this gives as the rate of change of the freezing point with pressure $0.00705^{\circ} \mathrm{C}$. per kilogram. MME. Marie Elisa P. RuMPF and Paur RUMPF : The ultra-violet spectra of the bromine deriva. tives of aniline. Georges CARPÉNI : The dissociation constants of reductone and of its oxidation product with iodine. JEAN CHÉDIN : The quantitative analysis by the Raman effect of mixtures of sulphuric and 
nitric acids. HenRI LemoNDE : Diffusion and azeotropism in binary mixtures. AlbBent Portevin and PAUL Bastien: The mechanical resistance of the skin of alumina and its influence on the surface tension of the fused metal. MME. Líone Walter LÉvY : Basic sulphocarbonate of magnesium. MaURICE Dodé : Study of the reactions taking place during the absorption of nitrous vapours by solutions of potassium iodide. JACQUEs BouRCART : Remarks on the Quaternary deposits on the Portuguese coast between Cap d'Espichel and the Peniche Peninsula. Mrde. Madeleine Fourcroy : The evolutive acceleration of the rootlets in wounded roots. YU CHIH. CHEN : A new technique analogous to the Feulgen reaction and its application to the study of the evolution of the nucleolar elements and satellites. M. and Mme. Fernand Moreau : The action of the sugars on the Saprolegnieæ. EmILE Perrot : A new plant containing colchicine, lofout, a liliceaceous plant from the Sahara. MaURICE HocQuetTe : Remarks on some characters of the secretion of Primula obconica. Evidence that the secretion in the cell and outside differ in composition. MME. CECIrE SOSA-BourdouIL: Comparisons between some peas and their hybrids, relating to the elementary composition of the seeds. Marc Srmonet New interspecific hybrids of 1ris Pogoniris. MuLe. M. GAUTHIER : A new entophyte of the Harpellaceæ group, parasite of the larvæ of Ephemerids. GrongES SovcHế: The nucleus of Diplocystis schneideri. Phurppe JoYet-Lavergne : The localisation of vitamin $A$ in the red corpuscles of the blood of the vertebrates in the course of the evolution of these globules. HenrI NouveL : Observations on abortive cells and the embryology of larvæ of the Dicyemides. Mme. LUCIE RandoIn and Roger Netree : Marked difference between the degree of necessity of vitamins $A$ and $B$ at a certain period of growth of the young rat, and in the case of a régime very rich in glucides. Muse. Laia Orszycka : Quantitative study of the phenomena of synergy. Contribution to the study of the mechanism of the phenomena of potentialisation of hypnotic action in the rat. ANToIne MagnaN and HENRY GIRERD: Attempts at recording the successive attitudes of the wings of a pigeon and the corresponding variations of pressure. MME. VERA DaNTChaKofF : The final result of a "female by hormonal induction". SERGE TCHaknotine : Localised irradiation of the myoneme of the peduncle of Vorticella by ultra-violet micropuncture. JACQUES RABatí and JEAN DUSSY : Contribution to the study of the flavonolic heterosides of the fruits of Sophora japonica. Pierre and Camule Chatagnon : The metabolism of bromine in the human organism. The tabulated results do not confirm the conclusions of Zondek and Bier. LouIs CoTONI and JACQUES POCHON : The titration of various therapeutic sera by neutralisation of the antibodies in vitro.

\section{BRUSSELS}

Royal Academy (Classe. Sci., December 7, 1935). L. GoDEAUX: An algebraic variety in three dimensions of geometric genus zero and bigenus one. J. E. Vhrschaffelt : Thermomechanics of the electric conductor (3). Reflections on the theory of the transverse magnetic effects. Comparison of the theory given in previous articles with the results of Sommerfeld and Franck. T. Solomos : Probable shape of the cross-section of Saturn's rings. The consequences of assuming a hyperbolic shape for the rings are examined. P. VAN Rysserberghe: The Le Chatelier-Braun principle and moderation theorems. R. Leprus : Probe measurements on the inverse alternation of mercury vapour rectifiers. Oscillographic studies. M. Désirant and J. Duchesne : Researches on the molecular spectrum of sulphur vapour. Extension of observations to longer wavelengths.

December 14, 1935. J. GÉHÉnIAU : Correspondence between gravitational fields and the fields of the wave mechanics. S. ARsitidysky : Logical bases of the theory of probability (1). Theories founded on the notion of the limit of the relative frequency. M. KouRENSKY : Reduction of the integration of systems of non-linear equations of the first order with partial derivatives of several unknown functions to the integration of systems of linear equations of the first order of a single unknown function.

December 16, 1935. J. E. Verschaffelt : Modern alchemy. H. Buttgenbach : Meteorites.

January 11, 1936. M. Winants: Both the two problems $a_{0}$, III, $3^{\prime \prime}$ and $a_{0}$, III, $2^{\prime}$ can be solved by means of an integral equation with an infinite number of terms. G. Fichtenholz : Linear operations in the space of continuous functions. G. DRINFELD : Integral invariants and contravariant functions. V. PÂQUET : The fundamental formula of the invariantive theory of the calculus of variations. O. RozeT: Some remarks on the deformation of quadrics. L. LONG : Some remarkable systems of curves on surfaces (3). L. Martin: On Bessel transcendents considered as Riemann functions relative to a class of systems of equations with partial derivatives containing as many equations as there are unknown functions of two independent variables. H. FredericQ : Changes of the action of the cardiac pneumogastric of the turtle produced by modifica. tions of the $p \mathrm{H}$ of the heart.

\section{ROME}

Royal National Academy of the Lincei (Atti, 22, 275365 ; 1935). U. CisotTI : (1) Criterion for evaluating the dynamic forces acting on a circular obstacle containing a source and immersed in a translocirculatory current. (2) Calculation of the 'ballast effects' relative to a rectilinear lamina. M. BetTi and M. MANzoni : Anomalies in the dissociation constants of some halogenated organic acids (2). The dissociation constant of 0 -chlorophenylacetic acid $\left(1 \cdot 35 \times 10^{-4}\right)$ is unexpectedly less than that of the corresponding bromo-acid $\left(1.92 \times 10^{-4}\right)$. G. CHEcchia-RIspoli: A Miocene formation from the Appennines of Capitanata. E. GUGINo : (1) Direction derivatives of tensors. (2) Cyclic transport of a tensor of any order. G. DoETsCH : Tricomi's formulæ on the polynomials of Laguerre. R. CACCIOPPoLI : Elliptical partial differential equations with two independent variables, and regular problems of the calculus of variations (1). U. BRogGr : Constants of FourierLaguerre. G. AscolI : A particular differential equation of the second order. L. SoNA: Translocirculatory current which invests a bilateral lamina. Integral of the motion (3). L. Gialanella : Meridian observations of Uranus in 1934 and of Mars in 1935. E. MEDI : New method of analysis of partially polarised light diffused from the sky. G. GrRAUD : Passage of electricity in a magnetic field when the electrodes are points. G. NATTA and R. Rigamonti : Examination by electron rays of some fatty esters. 
Long-chain compounds appear to show a twodimensional isomorphism, which is independent of the active terminal groups and persists when $\mathrm{CH}_{2}$ groups are replaced at long intervals by $\mathrm{CO}$ or by $\mathrm{O}$. G. $\mathrm{B}$. BoNINo and R. MANZONI-ANSIDEI : Raman spectrum of some derivatives of pyrrole. All the alkyl-sub. stituted pyrroles investigated give the two "pyrrole ring' lines at $1,460-1,520 \mathrm{~cm}^{-1}$ and $1,370-1,390 \mathrm{~cm} .^{-1}$. G. GoIDANICH : Observations on a rare disease of clover in Italy : anthracnose of Kabatiella caulivora (Kirchn.), Karak. M. Mrrolo : Presence and distribution of reducing substances in brain tissue. Values are given of the reducing power of different parts of the brain tissue of toads, rats, pigeons, rabbits, cats, sheep, horses and oxen.

\section{Forthcoming Events}

[Meetings marked with an asterisk are open to the public.] Monday, May 4

Victoria Institute, at 4.30.-Dr. H. C. Morton: "The Supposed Evolutionary Origin of the Soul".

IMPERIAL CoITEGe of SCIENCE AND TEChNOLOGY, at 5.30.-Prof. G. T. Morgan, F.R.S. : Hofmann Memorial Lecture.

Royal Geographical Society, at 8.30.-Baroness Ravensdale: "Persia in 1935".

\section{Tuesday, May 5}

Institute of Pathology and Research, St. Mary's Hospital, London, at 5.-Dr. F. L. Pyman, F.R.S.: "Recent Researches in Chemotherapy".

London School of Hygiene and Tropicar Medicine, at 5.30.-Prof. A. Butenandt: "Biochemistry of the Sterol Group" (succeeding lectures on May 7 and 8).*

Institution of Crvil Enatneers, at 6.-E. F. Relf: "Modern Developments in the Design of Aeroplanes" (James Forrest Lecture).

\section{Wednesday, May 6}

Royal Society of ARts, at 8.-G. Mackenzie Junner : "The Oil Engine and its Influence on Road, Rail and Air Transport".

Institute of Metals, at 8.- (at the Institution of Mechanical Engineers, Storey's Gate, S.W.1).-C. C. Paterson: "The Escape of Electricity from Metals : its Practical Consequences" (Annual May Lecture).

\section{Thursday, May 7}

BEDFORD COLLEGE FOR WOMEN, at 5.15.--Sir Edward Poulton, F.R.S. : "Ants".*

Royal Veterinary College, at 5.30.-Prof. Henry Dryerre and Dr. J. Russell Greig : "Mineral Deficiency Diseases of Farm Animals" (succeeding lecture on May 8).*

Institution of Elefotrical Enginezrs, at 6.-Annual General Meeting.

Dr. E. Mallet: "Television-An Outline" (Faraday Lecture).

\section{Friday, May 8}

Bedson Cldb (Armstrong College, Newcastie upon TYNE), at 6.30.-Dr. C. H. Desch, F.R.S.: "The Chemical Properties of Metals" (Bedson Lecture).

Royal Institution, at 9.- Sir William Bragg, Pres. R.S. : "The Electric Properties of Crystals (II)".

Iron AND Steel Institute, May 7-8.-Annual Meeting to be held at the Institution of Civil Engineers, Great George Street, London, S.W.1.

\section{Official Publications Received}

\author{
Great Britain and Ireland
}

County Borough of Southport : Meteorological Department: The Fernley Observatory, Southport. Report and Results of Observations for the Year 1934, with an Appendix. By Joseph Baxendell. Pp. 32. (Sonthport: Fernley Observatory.)
The Nutritive Value of Milk. Memorandum by the Advisory ComThe Nutritive Value of Milk. Memorandum by the Advisory Com-
mittee on Nutrition, issued by the Ministry of Health and the Department of Health for Scotland. Pp. 12. (London : H.M. Stationery Office.) $3 d$. net.
Ministry of Health. Costing Returns, Year ending 31st March Ministry of Health. Costing Returns, Year ending 31st March
1935. Pp. 24. (London: H.M. Stationery Office.) 18. net. Rothamsted Conferences. 21: The Use of Electricity in Agriculture : being a Report of a Conference held at Rothamsted on January 29 th, 1936, under the Chairmanship of Sir Bernard E. Greenwell. Contributions by Sir E. J. Russell, M. M. Harvey, B. A. Keen and G. H. Cashen, F. E. Rowland, C. A. Cameron Brown, and others. Pp. 77. (Harpenden: Rothamsted Experimental Station.) 28. [14 Report of the Marlborough College Natural History Society for the Year ending Christmas. 1935. (No. 84 .) Pp. 94+8 plates. (Marl borough : Marlborough College. 58 .; to Members, 38 . ment Commissioners, being for the Year ended 31st March 1935. mp. 141. (London: H.M. Stationery Office.) 28. 6d. net. Interim Report of the Departmental Committee on the Ordnance Survey. Pp. 16. (London : H.M. Stationery Office.) 3d. net. ${ }_{\text {The Economic Proceedings of the Royal Dublin Socjety. }}^{[24}$ No 1 : Factors infuencing the Loss of Butterfat in Churning. By J. Lyons and M. O'Shea. Pp. 18. (Dublin: Hodges, Figgis and Co.;
London : Williams and Norgate, Ltd.) 18.

\section{Other Countries}

Veröffentlichungen des Geophysikalischen Instituts der Universität Leipzig. Zweite Serie : Spezialarbeiten aus dem Geophysikalischen Institut und Observatorium. Band 7, Heft 1: Die Singularităt im Druckverlauf Ende November, ihr innerer Aufbau und ihr Einfluss auf den 'Temperaturverlauf Europas im Dezember (Weihnachtstauwetter). Von Fritz Engelmann. Pp. $52+16$ maps +3 plates. Band 7 Heft 2 Horizontale und vertikale Staubverteilung in einer Grossstadt. Von Aifred Löbner. Pp. 53-100+9 plates. Band 7, Heft 3: Zur Theorie der Luftspiegelungen insbesondere des elliptischen Falles. Von Wolf-Egbert Schiele. Pp. 101-188. (Leipzig : Geophysikalischen Institut.)

U.S. Department of Agriculture. Circular No. 381: Rodents and Moles as pests in Bulb Plantings. BY Theo. $H$. Scheffer and F. E. Garlough. Pp. 16. 5 cents. Technical Bulletin No. 504: Drius insidiosus (Say), an Important Natural Enemy of the Corn Ear Worm. By G. W. Barber. Pp. 24. 5 cents. (Washington, D.C. : Government Smithsonian Miscellaneous Collections. Vol. 95, No. 2: Lethal Effect of Short Wave Lengths of the Cltraviolet on the Alga Cklorella vulgaris. By Florence E. Meier. (Publication 3380.) Pp. $19+2$ plates. Vol. 95, No. 3 : Liquid-Propellant Rocket Development. By Robert H. Goddard. (Publication 3381). Pp. $10+11$ plates. (Washington, Koninklijk Nederlandsch Meteorologisch Instituut. No. 115: oceanographische en meteorologische Waarnemingen in de Chineesche Zeeën en in het Westelijk Deel van den Noord Stillen Oceaan. 1: Maandkaarten voor Januari-Juni (1910-1930). Pp. 48. ('s-Gravenhage: Rijksuitgeverij.) 7.50 fl.

League of Nations. Bulletin of Information on the Work of International Organisations. Compiled by the Section of Internationa Bureaux. (No. 2, Vol. 7.) Pp. 93-206. (Geneva: League of National London: George Allen and Unwin, Ltd.) Obras completas y Correspondencia cientiflca de Florentino Ameghino. Vol. 19: Obras póstumas y truncas. Edición Oflcial ordenada por el Gobierno de la Provincia de Buenos Aires. Dirigida
por Alfredo J. Torcelli. Pp. 1042. (La Plata.) por Alfredo J. Torcelli. Pp. 1042. (La Plata.)
Osiris. Vol. 2, Part 2: Speech Consciousness among Egyptians Osiris. Vol. 2, Part 2: Speech Consciousness among Egyptians
and Babylonians. By Henry Frederick Lutz. Pp. 27. (Bruges: and Babylonians. By Henry Frederick Lutz. Pp. 27. (Bruges:
Saint Catherine Press, Ltd.) Saint Catherine Press, Ltd.)
The Parliament of the Commonwealth of Australia. Ninth Annus] Report of the Council for Scientific and Industrial Research for the Year ended 30th June 1935. Pp. 108. (Canberra : Government Printer.) 48. 8d. June 1935. Pp. 108. (Canberra: Government
[64 Printer.)
Studja nad Bocianem Bialym w Polsce (Studies on the Stork (Ciconia ciconia L.) in Poland.) 2: Bocian na Polskim Sląsku ('The Stork in Polish Silesia). By Kazimierz Wodzicki. Pp. 20. 3 : Bocian w Wojewödztwie Lwowskiem (The Stork in the Voivodeship of Lwow). By Kazimierz Wodzicki. Pp. 44. (Kraków: Państwowej Rady Ochrony Przyrody.)

Państwowe Muzeum Archeologiczne. Wiadomości Archeologicznz, Odbitka $z$ tomu 13: Studja nad Prehistorycznemi Psami Polsk (Studien über vorgeschichtliche Hunde Polens). By Kazimierz Wodzicki. Pp. $74+7$ plates. (Warszawa: Państwowe Muzeum
Archeologiczne.)

\section{Catalogues}

Hortvet Cryoscope. (Circular No. 277B.) Pp. 2. Chemical Products. (Pamphlet No. 287.) Pp. 4. Useful Laboratory Requisites. (Circular No. 304.) Pp. 2. Humidity Controlled Cabinet. (Circular No. 306.) Pp. 2. (London: A. Gallenkamp and Co., Ltd.) Books on Botany, Gardens and Gardening, Forestry and Agriculture, with a section of Herbals. (Catalogue No. 599.) Pp. 34. ondon: Francis Edwards, Ltd.)

Chemie, Physik. 14 Verzeichnis antiquarischer Bücher und Zeitschriften nebst Novitatenliste. Pp. 32. (Berlin : Verlag Chemle,
G.m.b.H.) 